\title{
A Rapid Technique for the Evaluation of Potato Germ Plasm for Susceptibility to Pink Rot
}

\author{
R. D. Peters, Agriculture and Agri-Food Canada, Crops and Livestock Research Centre, P.O. Box 1210, \\ Charlottetown, PE, Canada C1A 7M8; and A. V. Sturz, PEI Department of Agriculture and Forestry, Plant Health \\ Research \& Diagnostics, P.O. Box 1600, Charlottetown, PE, Canada C1A 7N3
}

\begin{abstract}
Peters, R. D., and Sturz, A. V. 2001. A rapid technique for the evaluation of potato germ plasm for susceptibility to pink rot. Plant Dis. 85:833-837.

Disease-free plantlets of 20 potato cultivars commonly grown in Prince Edward Island were inoculated with zoospore suspensions of Phytophthora erythroseptica, the causal agent of pink rot, to determine disease response. All inoculated cultivars developed disease symptoms relative to noninoculated controls, but disease severity differed significantly $(P=0.05)$ among cultivars. Plantlets of the cultivars Goldrush and Yukon Gold were consistently the most susceptible to the disease, whereas plantlets of cultivars Butte and Russet Burbank were the least susceptible. Most of the cultivars assessed were moderately susceptible to disease. Plantlets of potato cultivars with late-season field maturity were more resistant to disease than those with early or midseason maturity. Isolates of P. erythroseptica from diverse regions of Prince Edward Island and Maine did not differ significantly $(P=0.05)$ in pathogenicity. The screening protocol described was a reliable technique to determine the relative resistance of nontuber potato germ plasm to disease, resulting from infection with $P$. erythroseptica.
\end{abstract}

Additional keywords: Oomycete, Solanum tuberosum

Pink rot of potato (Solanum tuberosum L.) caused by Phytophthora erythroseptica Pethyb. is an important disease in potatogrowing regions worldwide (25). The disease is particularly severe in poorly drained land when warm, wet climatic conditions persist at harvest time $(1,20)$. Underground potato tissues such as roots, stolons, tubers, and basal stems can be infected by $P$. erythroseptica. Root and stem infection can result in plant wilting and death, whereas tuber infection leads to pink rot development prior to harvest and in storage.

Long-term survival of the pathogen in soil is by means of oospores (26). P. erythroseptica has been isolated from the roots of asymptomatic, nonsolanaceous hosts (27), which suggests that other survival mechanisms can operate. Propagules of $P$. erythroseptica are endemic in most soils, but seed tubers infected superficially by diseased tubers in storage can produce infected daughter tubers and may be a

Corresponding author: R. D. Peters

E-mail: petersr@em.agr.ca

AAFC Contribution No. 968.

Accepted for publication 6 April 2001.

Publication no. D-2001-0525-01R

This article is in the public domain and not copyrightable. It may be freely reprinted with customary crediting of the source. The American Phytopathological Society, 2001. source of primary inoculum in uninfested soils (3). In this way, strains of P. erythroseptica also may be transported from one region to another. Tubers are usually infected via the growth of mycelium from diseased stolons. When adequate moisture is available and favorable temperatures occur, however, zoospores can infect tubers directly through buds or lenticels (25).

Most commercially grown potato cultivars in Canada and the United States are considered to be susceptible to pink rot, and breeding efforts to develop cultivars resistant to $P$. erythroseptica have been minimal. This is at least partially the result of the relative success of the chemical control of the pathogen, which is achieved through field applications of metalaxyl (30). Metalaxyl-resistant strains of $P$. erythroseptica, however, have been isolated in several potato-growing regions $(6,11,21)$, thus integrated pest management systems will become increasingly important if the failure of this active ingredient is to be avoided.

In the present study, we utilized tissue culture plantlets to assess the susceptibility of 20 commercially important potato cultivars to disease caused by infection with $P$. erythroseptica. We also determined the relative pathogenicity of the pathogen isolates from Prince Edward Island, Canada, and detailed a rapid protocol to screen nontuber potato germ plasm (roots, stems, and stolons) for resistance to pink rot.

\section{MATERIALS AND METHODS}

Isolates of Phytophthora erythroseptica. Isolates of $P$. erythroseptica used in inoculation studies were chosen from a larger collection of 97 isolates obtained from potato tubers with symptoms of pink rot collected from storages in Prince Edward Island in October 1999 (17). Protocols for the isolation and establishment of pure cultures were performed as described in Peters and Sturz (16) and Peters et al. (17). Field isolates were grown in V8 broth and incubated in sterile pond water to stimulate the release of zoospores, which were subsequently plated onto $1.5 \%$ water agar to generate single zoospore isolates (17). Isolates were maintained on V8 agar slants at $12^{\circ} \mathrm{C}$ for routine use and in $10 \%$ glycerol at $-80^{\circ} \mathrm{C}$ for long-term storage (16).

In an attempt to incorporate the genetic diversity in nature into the inoculation studies, four single zoospore isolates of $P$. erythroseptica (PE9906-1BSZ2, PE99091CSZ2, PE9910-1DSZ1, and PE99132DSZ1) recovered from spatially distant and diverse climatic zones across Prince Edward Island were selected. In addition, one single zoospore isolate (ME99C5SZ3) of $P$. erythroseptica derived from a field isolate from Maine (courtesy of D. H. Lambert, University of Maine, Orono) also was incorporated into the test. Preliminary in vitro assays determined diversity at loci coding for resistance to metalaxyl; ME99C5SZ3 was resistant to metalaxyl compared with the metalaxyl-sensitive isolates recovered from Prince Edward Island (17).

Source of plantlets. Microplantlets of each cultivar (source: Elite Seed Farm, Alberton, PEI, Canada) were multiplied in vitro on Murashige and Skoog basal salts with minimal organics, micronutrients, and vitamins (MSMO, product no. M6899; Sigma, St. Louis, MO) in GA3 magenta vessels with single-node explants taken from 4-week-old stock plants grown from disease-indexed single nodal cuttings.

Inoculation studies. Twenty of the most commercially important potato cultivars grown in Prince Edward Island were evaluated (Table 1). Microplantlets of 6 to $7 \mathrm{~cm}$ were transplanted into moistened vermiculite (medium-grade Holiday; VIL Vermiculite, Toronto, ON, Canada) in 72cell black plastic inserts (Kord Products, Bramalea, ON, Canada), which were held 
in S1020 black plastic flats with holes (Kord Products). The experiment was set out in a growth room at $18^{\circ} \mathrm{C}$, under 400 W sodium lamps (P. L. Light Systems, Beamsville, ON, Canada) that were located $85 \mathrm{~cm}$ above the foliage (14-h photoperiod). Plantlets were watered daily prior to inoculation.

In two experiments, plantlets of the 20 potato cultivars chosen for study were inoculated with zoospore suspensions of each of the five different single zoospore isolates of $P$. erythroseptica (PE99061BSZ2, PE9909-1CSZ2, PE9910-1DSZ1, PE9913-2DSZ1, and ME99C5SZ3). Each experiment examined the response of plantlets of 10 different potato cultivars (Groups I and II cultivars) to separate inoculation with five single zoospore isolates.

Inoculation of the plantlets was carried out 7 days following transplantation. All plantlets were flooded by placing flats into clear domes (Kord Products) filled with cold tap water. The isolates of $P$. erythroseptica chosen for study were stimulated to produce zoospores in sterile pond water with the use of a protocol described by Peters et al. (17). To encourage zoospore release at inoculation, isolates growing in sterile pond water in 50-ml plastic disposable sterile centrifuge tubes (Fisher Scientific, Nepean, ON, Canada) at $18^{\circ} \mathrm{C}$ were chilled at $9^{\circ} \mathrm{C}$ for $1.5 \mathrm{~h}$ and then held at $22^{\circ} \mathrm{C}$ in the dark for $30 \mathrm{~min}$ (17). Zoospore concentrations in each centrifuge tube were determined with a hemacytometer and standardized to $3 \times 10^{4}$ zoospores per $\mathrm{ml}$ with sterile pond water. Inoculation was carried out by pipetting $1 \mathrm{ml}$ of zoospore suspension onto each plantlet with a micropipette. Disposable pipette tips were replaced between inoculation treatments involving different isolates. Zoospore suspensions were kept at $9^{\circ} \mathrm{C}$ during the course of inoculation to maintain zoospore motility. Trial controls were plantlets inoculated only with sterile pond water.

Plantlets were flooded for 3 days, after which plastic domes were removed and flats allowed to drain. Plantlets were fertilized with $10 \mathrm{ml}$ of Plant-Prod 20-20-20 concentrated water-soluble fertilizer (Plant Products, Brampton, ON, Canada) at half the recommended rate $(3 \mathrm{ml}$ of product per 5 liters of water) at 7 days following inoculation. At 10 days after inoculation, the experiment was ended. Plantlets were harvested, washed in running water, and evaluated for disease severity with a disease severity index (DSI), modified from Shang et al. (22), where: 1 = no discoloration of roots; stem and foliage is healthy and green; 2 = slight necrosis of roots; stem and foliar symptoms are absent or there is chlorosis of lower leaves; $3=$ necrosis of roots and lower stem; foliar symptoms are absent or include chlorosis/necrosis of lower leaves; $4=$ extensive necrosis of roots and stem; a lesion traveling up the stem causing pinching, wilting, chlorosis, or necrosis of foliage; and $5=\mathrm{a}$ dead plantlet.

To confirm the presence of $P$. erythroseptica in diseased tissues, random tissue samples were taken from plantlets of each cultivar, surface-sterilized in $0.6 \%$ sodium hypochlorite for $30 \mathrm{~s}$, rinsed twice in sterile distilled water, and blotted dry on Whatman No. 4 sterile filter paper (Kent, U.K.). Tissue pieces were then plated onto $1.5 \%$ water agar in small $(60 \times 15 \mathrm{~mm})$ petri dishes and incubated in the dark at $22^{\circ} \mathrm{C}$ for 3 to 4 days, after which dishes were examined for $P$. erythroseptica growth.

Each experiment was repeated once, for a total of two runs for each group (Groups I and II) of 10 cultivars. All four trials were conducted over a period of 6 months
(March to August 2000) to limit the effects of environmental variation on plantlet response. The trials were designed as a split plot, with the isolate as the main plot factor and the cultivar as the subplot factor. Groups of six plantlets of a particular cultivar were assigned randomly to one of three replicate blocks (18 plantlets of a cultivar were assessed per isolate in each trial). The split-plot design was chosen to segregate isolates among flats, thus excluding the possibility of cross-contamination within a flat.

Data analysis. Data for DSI values were analyzed by analysis of variance with Genstat 5, release 3(1) (Numerical Algorithms Group, Oxford, U.K.). When a significant treatment effect was found, the test of least significant difference $(P=0.05)$ was used to separate means. Data for multiple trials were pooled following tests for homogeneity of variance. The main effect means of cultivar response to infection with multiple isolates were compared when cultivarisolate interactions were not significant. Because no disease developed in noninoculated controls, they were excluded from the analysis. Cultivars were classed as highly susceptible (HS), moderately susceptible (MS), moderately resistant (MR), or highly resistant (HR), according to the mean DSI (HR: $1 \leq \mathrm{DSI} \leq 2$; MR: $2<\mathrm{DSI} \leq 3$; MS: 3 $<$ DSI $\leq 4$; and HS: $4<$ DSI $\leq 5$ ). Cultivars also were grouped by crop maturity, and disease data was subjected to analysis of variance to compare mean disease severity of early- to midseason cultivars with lateseason cultivars.

\section{RESULTS}

Inoculation studies. Of the 20 potato cultivars inoculated with zoospores of $P$. erythroseptica, none were immune or highly resistant to disease. The pathogen was reisolated from tissue samples of each

Table 1. Characteristics of potato cultivars screened for response to inoculation with isolates of Phytophthora erythroseptica ${ }^{\mathrm{z}}$

\begin{tabular}{|c|c|c|c|c|}
\hline Cultivar & Skin color & Tuber shape & Maturity & Parentage \\
\hline AC Novachip & White & Oblong & Midseason & F68061 × F66011 \\
\hline Atlantic & Buff & Oval to round & Midseason & Wauseon $\times$ B5141-6 \\
\hline Butte & Dark buff & Long & Very late & A492-2 × Norgold Russet \\
\hline Century Russet & Light russet & Blocky to long & Very late & A6789-7 × A6680-5 \\
\hline Chieftain & Bright red & Round oval & Midseason & La1027-18 × La1354 \\
\hline Frontier Russet & Light russet & Oblong to long & Midseason & A66102-16 × WN330-1 \\
\hline Goldrush & Russet & Long & Midseason & Lemhi Russet $\times$ ND450-3 Russ \\
\hline Green Mountain & Buff & Oblong, flattened & Late & Dunmore $\times$ Excelsior \\
\hline Hilite Russet & Light russet & Long & Early & Unknown \\
\hline Kennebec & Buff & Elliptical to oblong & Midseason & B127 × USDA $96-56$ \\
\hline Krantz & Russet & Blocky oblong & Midseason & MN366.65-3 × G6743-5 \\
\hline Ranger Russet & Tan-brown & Long & Very late & Butte $\times$ A6595-3 \\
\hline Red Pontiac & Dark red & Oblong to round & Midseason & Mutation of Pontiac (Triumph $\times$ Katahdin) \\
\hline Russet Burbank & Russet & Long & Very late & Mutant of Burbank (seed ball from Early Rose) \\
\hline Russet Norkotah & Dark russet & Long & Midseason & ND9526-4 Russ $\times$ ND9687-5 Russ \\
\hline Sebago & Buff & Round & Very late & Chippewa $\times$ Katahdin \\
\hline Shepody & Buff & Long & Midseason & Bake King $\times$ F58050 \\
\hline Snowden & Buff & Round to oval & Late & B5141-6 × Wischip \\
\hline Superior & Buff & Round & Early midseason & B96-56 × M59.44 \\
\hline Yukon Gold & Yellow buff & Oval & Midseason & W5279-4 × Norgleam \\
\hline
\end{tabular}

z Adapted from Potato Varieties in Canada, 5th ed. 1993. G. M Barclay and W. W. M. Schrage, eds. Canada-New Brunswick Cooperation Agreement on Agri-Food Development. 
cultivar, receiving zoospore inoculations in all cases. Differential disease responses, measured 7 to 10 days following inoculation, were grouped according to a DSI (Fig. 1A). The severity of disease varied significantly $(P=0.05)$ among cultivars (Fig. 1B), although cultivar responses were consistent across trials. Data for multiple trials were pooled following tests for homogeneity of variance.

In the most severe host-pathogen interactions, necrotic, water-soaked lesions rapidly moved upward from the stem base, resulting in stem pinching, plant wilting, and subsequent chlorosis/necrosis of the foliage (Fig. 1C). Additionally, plantlet roots were necrotic and virtually destroyed. Less severe reactions included basal stem lesions that failed to progress up the stem, accompanied by root necrosis and chlorosis or necrosis of lower leaves. Mild reactions included a slight necrosis of roots and chlorosis of lower leaves. In some cultivars, particularly Frontier Russet, Krantz, and Superior, the formation of aerial tubers was common (Fig. 1D). In those cultivars least affected, necrotic flecking, similar to a typical hypersensitive response, was often noted on roots and basal stem tissue. Plantlets inoculated with sterile pond water did not develop disease symptoms.

Analysis of variance indicated significant differences $(P<0.001)$ in cultivar response to infection (Table 2). Cultivarisolate interactions were not significant, so the main effects could be compared. The majority $(60 \%)$ of cultivars were classed as MS, 20\% were classed as HS, and $20 \%$ were classed as MR. Of the Group I cultivars assessed (Table 2), Goldrush and AC Novachip were the most susceptible to disease and Butte the least susceptible. Of the Group II cultivars assessed (Table 2), Yukon Gold and Shepody were the most susceptible to disease, whereas Russet Burbank was the least susceptible.

Cultivar resistance to $P$. erythroseptica infection in potato plantlet tissues (stem, root, and stolon) was associated with cultivar time to field maturity (Table 3 ). Plantlets of potato cultivars with late-season field maturity were significantly $(P<$ $0.001)$ more resistant to disease development than those with early or midseason maturity (Table 4).

There was no significant difference $(P=$ $0.05)$ in the ability of metalaxyl-sensitive (from PEI) and -resistant (from Maine) isolates to induce disease. All isolates responded similarly, in terms of pathogenicity, in plantlet inoculation trials.

\section{DISCUSSION}

Although the severity of an outbreak of pink rot is often assessed in terms of tuber rot, infection of other plant tissues can significantly compromise plant vigor, tuber bulking, and consequently, harvestable yield. All underground potato tissues (roots, stolons, tubers, basal stems) can be infected by $P$. erythroseptica, and root and stem infection generally results in plant wilting, plant death, and subsequent yield losses prior to harvest and storage. Stem infection progressing aboveground, chlorosis of basal leaves, premature abscission, wilt, and plant death (25) all interrupt the tuber-bulking process. Similarly, destruction of plant stems and associated vascular bundles in advance of stem necrosis and the production of aerial "tubers" in leaf axils (18) is evidence of the disruption of translocation of photosynthates to developing tubers (14) and the diversion of photosynthate to other than tubers belowground, resulting in reduced tuber size. Belowground, the death of stolons prior to tuberization will reduce tuber number.

The importance of root, stolon, and stem infection in the disease cycle and the lack of information on the relative responses of nontuber germ plasm of common potato cultivars to $P$. erythroseptica infection provided the stimulus to develop the protocol outlined in this study. Inoculation of disease-free potato plantlets with zoospore suspensions of $P$. erythroseptica resulted in the development of disease symptoms of different severity among cultivars. The screening system was rapid (17 days from planting to disease ratings) and reliable, and the results were consistent among trials, supporting the use of this method as part of any assessment to evaluate potato germ plasm for resistance to $P$. erythroseptica in root, stolon, and stem tissues. The system is probably not a useful indicator of tuber resistance to pink rot disease development, however, which is likely to be influenced by a different set of criteria.

In the present study, the parentage of commonly grown potato cultivars (Table 1) may provide clues to sources of disease resistance in potato plant tissues. For example, breeding line F58050 is in the pedigrees of Shepody and AC Novachip $(4,28)$, two cultivars which responded similarly to plantlet inoculation with isolates of $P$. erythroseptica (Table 2). Likewise, Ranger Russet and Butte were classed as moderately resistant to disease (Butte is one of the parents of Ranger Russet) (Table 1).
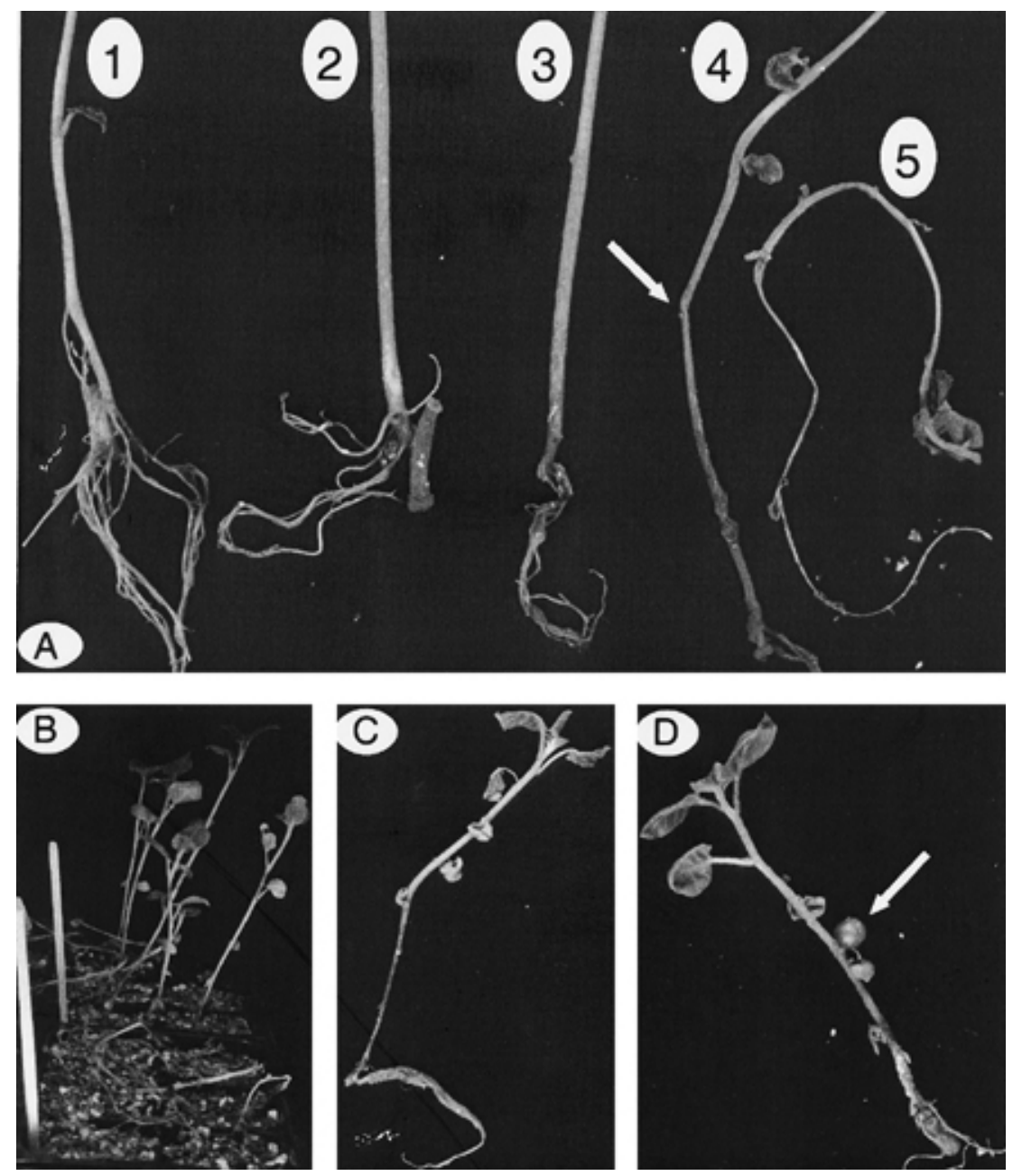

Fig. 1. Symptoms of infection of potato plantlets by Phytophthora erythroseptica. A, Disease severity categories (1 to 5) ranging from healthy (1) to dead (5) plantlets. Arrow indicates lesion, which caused stem pinching and subsequent wilting and necrosis of foliage. B, Plantlets of highly susceptible (foreground) and moderately resistant (background) cultivars. C, Progression of stem lesion in a highly susceptible cultivar, resulting in wilting and foliar chlorosis/necrosis. D, Formation of an aerial tuber (arrow) in a plantlet of cultivar Superior. 
Thus, isolates of $P$. erythroseptica could be used as biological probes to identify loci involved in disease resistance.

Because early tuber infection can involve mycelium entering the tubers via infected stolons (25), resistance mechanisms that retard the spread of the pathogen within the plant would provide some measure of disease control. Where adequate moisture is available, however, zoospores can still infect tubers through buds or lenticels (25). From our own field observations and data from other tuber rot experiments, we found that tubers from cultivars such as Russet Burbank, which were moderately resistant to infection by $P$. erythroseptica in the present study, could still become severely diseased when inoculated with a droplet of zoospore suspension at the eye (R. D. Peters and A. V. Sturz, unpublished data).

Parallel studies of tuber infection by Phytophthora infestans suggest that the intact periderm provides the principal barrier to pathogen penetration $(7,15)$ and that subsequent infections develop only through wounds, eyes, and lenticels $(7,12,15,29)$. Negative correlations between the resistance of potato foliage to infection by $P$. infestans and the resistance of the tubers (foliar resistance/tuber susceptibility or foliar susceptibility/tuber resistance) $(2,5$, $8,9,19)$ also have been reported. We speculate that the mechanism of tuber infection by swimming zoospores elicits a different set of defense responses in the host compared with those that operate in stems, stolons, or root tissues. For example, Sturz and Matheson (24) showed that the progression of Erwinia spp.-induced bacterial soft rots correlated negatively with the density of the tuber populations of endophytic bacteria able to inhibit Erwinia carotovora cv. atroseptica growth in vitro.
Similarly, antibiosis of bacterial endophytes against $P$. infestans $\left(\mathrm{A}_{1}\right.$ and $\mathrm{A}_{2}$ mating types) was significantly better in isolates recovered from the outermost layer of tuber peel and decreased progressively toward the center of the tuber, suggesting that endophyte-mediated defense mechanisms can be tissue-site specific (23).

Although more $P$. erythroseptica isolates need to be tested, those selected for plantlet inoculations did not differ significantly $(P=0.05)$ in pathogenicity. This implies that variability for isolate pathogenicity is

Table 3. Number of potato cultivars in groups defined by crop maturity and resistance of plantlet tissues (stem, root, and stolon) to infection by Phytophthora erythroseptica

\begin{tabular}{lcccc}
\hline & \multicolumn{4}{c}{ Crop maturity } \\
\cline { 2 - 5 } Resistance & Early & Midseason & Late & Very late \\
\hline Highly susceptible & 0 & 4 & 0 & 0 \\
Moderately susceptible & 1 & 8 & 1 & 2 \\
Moderately resistant & 0 & 0 & 1 & 3 \\
\hline
\end{tabular}

Table 4. Mean disease severity index (DSI) of early/mid-season and late-season potato cultivars found within Group I and Group II

\begin{tabular}{lccc}
\hline & \multicolumn{3}{c}{ Mean disease severity index } \\
\cline { 2 - 4 } Cultivar group & Early-midseason & Late season & Level of significance \\
\hline Group I & 3.71 & 3.08 & $P<0.001$ \\
Group II & 3.83 & 2.93 & $P<0.001$ \\
\hline
\end{tabular}

Table 2. Response of plantlets of 20 potato cultivars (Groups I and II) to inoculation with single-zoospore isolates of Phytophthora erythroseptica from Prince Edward Island and Maine

\begin{tabular}{|c|c|c|c|c|c|c|c|}
\hline \multirow[b]{2}{*}{ Cultivar/isolate } & \multicolumn{5}{|c|}{ Disease severity $^{u}$} & \multirow[b]{2}{*}{$\operatorname{Mean}^{\mathrm{x}}$} & \multirow[b]{2}{*}{ Class $^{\mathrm{y}}$} \\
\hline & PE9906-1BSZ2 $^{\mathrm{v}}$ & PE9909-1CSZ2 $^{\mathrm{v}}$ & PE9910-1DSZ1 $^{v}$ & PE9913-2DSZ1 $^{v}$ & ME99 C5SZ3 $^{w}$ & & \\
\hline \multicolumn{8}{|l|}{$\overline{\text { Group I }}$} \\
\hline Goldrush & 4.75 & 4.53 & 4.72 & 4.64 & 4.78 & $4.68 \mathrm{a}$ & HS \\
\hline AC Novachip & 4.14 & 4.78 & 4.03 & 3.81 & 3.86 & $4.12 \mathrm{~b}$ & HS \\
\hline Green Mountain & 3.75 & 4.25 & 3.86 & 3.75 & 4.08 & $3.94 \mathrm{c}$ & MS \\
\hline Chieftain & 3.61 & 3.78 & 3.28 & 3.44 & 3.53 & $3.53 \mathrm{~d}$ & MS \\
\hline Century Russet & 3.28 & 3.69 & 3.08 & 3.36 & 3.22 & $3.33 \mathrm{e}$ & MS \\
\hline Frontier Russet & 3.14 & 3.44 & 3.28 & 2.75 & 3.28 & $3.18 \mathrm{ef}$ & MS \\
\hline Krantz & 3.03 & 3.31 & 2.97 & 2.94 & 2.92 & $3.03 \mathrm{fg}$ & MS \\
\hline Ranger Russet & 2.78 & 3.44 & 2.64 & 2.94 & 3.17 & $2.99 \mathrm{gh}$ & MR \\
\hline Snowden & 2.94 & 2.97 & 2.89 & 2.78 & 2.67 & $2.85 \mathrm{~h}$ & MR \\
\hline Butte & 2.33 & 2.58 & 2.14 & 2.06 & 2.28 & $2.28 \mathrm{i}$ & MR \\
\hline Mean SEM $0.15(360,16)^{\mathrm{z}}$ & $3.38 \mathrm{a}$ & $3.68 \mathrm{a}$ & $3.30 \mathrm{a}$ & $3.25 \mathrm{a}$ & $3.38 \mathrm{a}$ & & \\
\hline \multicolumn{8}{|l|}{ Group II } \\
\hline Yukon Gold & 4.25 & 4.67 & 4.5 & 4.47 & 4.56 & $4.49 \mathrm{a}$ & HS \\
\hline Shepody & 4.17 & 4 & 4.44 & 3.94 & 3.94 & $4.10 \mathrm{~b}$ & HS \\
\hline Russet Norkotah & 4.06 & 4 & 3.81 & 4.17 & 3.97 & $4.00 \mathrm{~b}$ & MS \\
\hline Red Pontiac & 3.97 & 3.97 & 4.06 & 4.06 & 3.53 & $3.92 \mathrm{~b}$ & MS \\
\hline Kennebec & 3.5 & 4.06 & 3.61 & 3.64 & 3.61 & $3.68 \mathrm{c}$ & MS \\
\hline Superior & 3.81 & 3.67 & 3.53 & 3.44 & 3.56 & $3.60 \mathrm{~cd}$ & MS \\
\hline Hilite Russet & 3.75 & 3.47 & 3.33 & 3.64 & 3.14 & $3.47 \mathrm{de}$ & MS \\
\hline Atlantic & 3.47 & 3.53 & 3.33 & 3.36 & 3.28 & $3.39 \mathrm{e}$ & MS \\
\hline Sebago & 3.44 & 3.33 & 3.25 & 3.31 & 3.06 & $3.28 \mathrm{e}$ & MS \\
\hline Russet Burbank & 2.58 & 2.56 & 2.78 & 2.61 & 2.42 & $2.59 \mathrm{f}$ & MR \\
\hline Mean SEM $0.10(360,16)^{z}$ & $3.70 \mathrm{a}$ & $3.73 \mathrm{a}$ & $3.66 \mathrm{a}$ & $3.66 \mathrm{a}$ & $3.51 \mathrm{a}$ & & \\
\hline
\end{tabular}

" Means determined on the basis of pooled data from two experiments, with each experiment containing three replications and six observations/replication of each isolate/cultivar combination. Disease severity index (DSI): $1=$ healthy plantlet; $5=$ dead plantlet.

${ }^{v}$ Metalaxyl-sensitive single zoospore isolates of P. erythroseptica from diverse geographic regions of Prince Edward Island, Canada.

${ }^{\mathrm{w}}$ Metalaxyl-resistant single zoospore isolate of P. erythroseptica from Maine.

${ }^{x}$ Column means followed by the same letter within each group of cultivars (Group I and II) are not significantly $(P=0.05)$ different on the basis of a protected test of least significant difference (LSD $=0.1801$ [Group I] or 0.1943 [Group II]). Standard error of the mean (SEM) is 0.0645 (Group I) or 0.0985 (Group II). Number of observations per mean/error degrees of freedom are 180/180 for the main effect means in Group I and II.

y Cultivars were classed as highly susceptible (HS), moderately susceptible (MS), moderately resistant (MR), or highly resistant (HR), according to the mean DSI: HR $(1 \leq \mathrm{DSI} \leq 2)$; $\mathrm{MR}(2<\mathrm{DSI} \leq 3)$; MS $(3<\mathrm{DSI} \leq 4)$; HS $(4<\mathrm{DSI} \leq 5)$.

${ }^{\mathrm{z}}$ Row means followed by the same letter are not significantly $(P=0.05)$ different on the basis of a protected test of LSD $(0.4418$ for Group I or 0.2890 in Group II). SEM is followed by the number of observations per mean and error degrees of freedom (in parentheses). 
low, at least for those isolates from Prince Edward Island, which simplifies decisions concerning the source of inoculum for screening for resistance in breeding lines.

Although pink rot is commonly considered a disease of mature plants (13), note that those cultivars most resistant to plantlet infection and subsequent disease development tend to be late maturing (Tables 1, 3 , and 4). If this tendency for earlymaturing cultivars to be more susceptible than late-maturing cultivars holds true, there may be a genetic basis for the relationship between susceptibility to pink rot and host maturity, further underscoring the need for potato-breeding programs to assess root, stolon, and stem tissue when evaluating germ plasm for disease resistance. Recent work by Kimpinski et al. (10) revealed that, unlike early-maturing potato cultivars, late-maturing potato cultivars did not achieve yield benefits from field applications of nematicides, implying that the level of resistance to natural populations of root lesion nematodes is higher in late-maturing cultivars. More study is needed to characterize any possible genetic link between crop maturity and resistance to pathogens.

We argue that the apparent relationship among stem, stolon, and root tissue resistance to infection and disease progression warrants earlier applications of metalaxyl than recommended presently. Clearly, the presence of metalaxyl-resistant strains of $P$. erythroseptica in the soil population indicates that applications of metalaxyl will increasingly become less effective. Selecting those potato cultivars that better resist infection and disease development in stem, stolon, and root tissues is one strategy to employ in fields at risk, namely, those with high inoculum levels of the pathogen and poor soil-drainage properties. Plantlet inoculation experiments of the type outlined in the present study would provide information to enable growers to better time their fungicide applications, assist in the potato cultivar selection process, and provide breeders with a tool to evaluate potato germ plasm for disease resistance.

\section{ACKNOWLEDGMENTS}

We thank the PEI Potato Board, PEI Potato Producers Association, Agriculture Research Investment Fund (ARIF), and PEI Department of
Agriculture and Forestry for financial contributions. We also thank J. Mann, C. Banks, R. Clark, B. G. Matheson, and A. D. Coffin for technical assistance.

\section{LITERATURE CITED}

1. Bonde, R. 1938. The occurrence of pink-rot and wilt in Maine. Plant Dis. Rep. 22:460.

2. Bonde, R., Stevenson, F. J., and Clark, C. F. 1940. Resistance of certain potato varieties and seedling progenies to late blight in the tubers. Phytopathology 30:733-748.

3. Cunliffe, C., Lonsdale, D., and Epton, H. A. S. 1977. Transmission of Phytophthora erythroseptica on stored potatoes. Trans. Br. Mycol. Soc. 69:27-30.

4. De Jong, H., Tai, G. C. C., Murphy, A. M., Tarn, T. R., Thorpe, J. H. E., Arsenault, W. J., Bagnall, R. H., Platt, H. W., and Young, D. A. 1995. AC Novachip: A new potato cultivar with excellent chip quality after long storage and reconditioning. Am. Potato J. 72:417-425

5. Gallegly, M. E. 1968. Genetics of pathogenicity of Phytophthora infestans. Annu. Rev. Phytopathol. 6:375-396.

6. Goodwin, S. B., and McGrath, M. T. 1995. Insensitivity to metalaxyl among isolates of Phytophthora erythroseptica causing pink rot of potato in New York. Plant Dis. 79:967.

7. Hirst, J. M., Stedman, O. J., Lacey, J., and Hide, G. A. 1965. The epidemiology of Phytophthora infestans: IV. Spraying trials, 1959 to 1963 , and the infection of tubers. Ann. Appl. Biol. 55:373-395.

8. Inglis, D. A., Johnson, D. A., Legard, D. E., Fry, W. E., and Hamm, P. B. 1996. Relative resistances of potato clones in response to new and old populations of Phytophthora infestans. Plant Dis. 80:575-578.

9. Kadish, D., Grinberger, M., and Cohen, Y. 1990. Fitness of metalaxyl-sensitive and metalaxyl-resistant isolates of Phytophthora infestans on susceptible and resistant potato cultivars. Phytopathology 80:200-205.

10. Kimpinski, J., Arsenault, W. J., and Sturz, A. V. Differential effect of nematicide treatments on tuber yields in early- and late-maturing potato cultivars. Plant Pathol. In press.

11. Lambert, D. H., and Salas, B. 1994. Metalaxyl insensitivity of Phytophthora erythroseptica isolates causing pink rot of potato in Maine. Plant Dis. 78:1010.

12. Lapwood, D. H. 1977. Factors affecting the field infection of potato tubers of different cultivars by blight (Phytophthora infestans). Ann. Appl. Biol. 85:23-42.

13. Lennard, J. H. 1980. Factors influencing the development of potato pink rot (Phytophthora erythroseptica). Plant Pathol. 29:80-86.

14. Lonsdale, D., Cunliffe, C., and Epton, H. A. S. 1980. Possible routes of entry of Phytophthora erythroseptica Pethyb. and its growth within potato plants. Phytopathol. Z. 97:109-117.

15. Pathak, N., and Clarke, D. D. 1987. Studies on the resistance of the outer cortical tissues of the tubers of some potato cultivars to Phy tophthora infestans. Physiol. Mol. Plant Pathol. 31:123-132.

16. Peters, R. D., and Sturz, A. V. 2001. Application of a simple freezing method for shortterm storage of Phytophthora erythroseptica. Can. J. Plant Pathol. 23:106-109.

17. Peters, R. D., Sturz, A. V., Matheson, B. G., Arsenault, W. J., and Malone, A. Metalaxyl sensitivity of isolates of Phytophthora erythroseptica in Prince Edward Island. Plant Pathol. 50:302-309.

18. Pethybridge, G. H. 1914. Further observations on Phytophthora erythroseptica Pethyb. and on disease produced by it in the potato plant. Sci. Proc. R. Dub. Soc. 14:179-198.

19. Roer, L., and Toxopeus, H. J. 1961. The effect of R-genes for hypersensitivity in potatoleaves on tuber resistance to Phytophthora infestans. Euphytica 10:35-42.

20. Rowe, R. C., and Nielsen, L. W. 1986. Pink rot. Pages 39-40 in: Compendium of Potato Diseases. W. J. Hooker, ed. American Phytopathological Society, St. Paul, MN.

21. Salas, B., Secor, G. A., and Gudmestad, N. C. 1998. Sensitivity of Phytophthora erythroseptica to metalaxyl. (Abstr.) Am. J. Potato Res. 75:297.

22. Shang, H., Grau, C. R., and Peters, R. D 2000. Evidence of gene flow between pea and bean pathotypes of Aphanomyces euteiches. Can. J. Plant Pathol. 22:265-275.

23. Sturz, A. V., Christie, B. R, Matheson, B. G., Arsenault, W. J., and Buchanan, N. 1999. Endophytic bacterial communities in the periderm of potato tubers and their potential to improve resistance to soil-borne plant pathogens. Plant Pathol. 48:360-370.

24. Sturz, A. V., and Matheson, B. G. 1996. Populations of endophytic bacteria which influence host-resistance to Erwinia-induced bacterial soft rot in potato tubers. Plant Soil 184:265271.

25. Vargas, L. A., and Nielsen, L. W. 1972. Phytophthora erythroseptica in Peru: Its identification and pathogenesis. Am. Potato J. 49:309-320.

26. VujiFiD, R., and Park, D. 1964. Behaviour of Phytophthora erythroseptica in soil. Trans. Br. Mycol. Soc. 47:455-458.

27. Whelan, J., and Loughnane, J. B. 1969. Nonsolanaceous hosts of Phytophthora erythroseptica. Sci. Proc. R. Dub. Soc. Ser. B 2:171-178.

28. Young, D. A., Tarn, T. R., and Davies, H. T. 1983. Shepody: A long, smooth, whiteskinned potato of medium maturity with excellent French fry quality. Am. Potato J. 60:109-113.

29. Zan, K. 1962. Activity of Phytophthora infestans in soil in relation to tuber infection. Trans. Brit. Mycol. Soc. 45:205-221.

30. Zink, R. T. 1995. The effect of metalaxyl on the incidence of pink rot. (Abstr.) Am. Potato J. 72:665-666. 